\title{
PENGELOLAAN DANA TABARRU' PADA ASURANSI SYARIAH DAN RELASINYA DENGAN FATWA DEWAN SYARIAH NASIONAL
}

\author{
Amalia Fadilah', ${ }^{1}$ Makhrus ${ }^{2}$ \\ 1Universitas Muhammadiyah Purwokerto, Email : amaliafadilah9@gmail.com \\ 2Universitas Muhammadiyah Purwokerto, Email : makhrus.ahmadi@gmail.com
}

\begin{abstract}
ABSTRAK
Salah satu hal yang membedakan antara asuransi syariah dengan asuransi konvensional yakni adanya dana tabarru' pada asuransi syariah. Dana tabarru' merupakan dana tolong menolong atau hibah. Artikel ini mendiskusikan mengenai pengelolaan dana tabarru' dan kesesuaian dalam mengelola dana tabarru' Fatwa Dewan Syariah Nasional Majelis Ulama Indonesia Nomor. 53/ DSN-MUI/ III/ 2006 tentang akad tabarru'. Oleh sebab itu, hasil penelitian dalam artikel ini menggunakan jenis penelitian kualitatif-deskriptif dengan teknik pengumpulan data wawancara dan dokumentasi. Sedangkan objek penelitian berada di PT. Asuransi Takaful Keluarga Kabupaten Purbalingga dan PT. Asuransi Takaful Keluarga Purwokerto. Hasil penelitian dalam artikel ini menunjukkan bahwa setiap produk asuransi yang terdapat di PT. Asuransi Takaful Keluarga Kabupaten Purbalingga dan PT. Asuransi Takaful Keluarga Purwokerto telah menerapkan akad tabarru'. Pengelolaan dana secara keseluruhan terbagi menjadi tiga yaitu dana peserta, dana perusahaan, dan dan tabarru'. Dana tabarru' menjadi dana tolong menolong antar peserta asuransi syariah yang terkena musibah yang pembayaran klaim dialokasikan langsung dari pos dana tabarru' yang dipisahkan dari dana lainnya. Dana tabarru' dapat diambil dengan cara pengajuan klaim, tanpa pegajuan klaim, maka dana tabarru' tidak dapat diambil. Sementara dalam aspek pengelolaan dana tabarru' yang terkumpul oleh pihak perusahaan asuransi syariah diinvestasikan ke dalam instrumen investasi yang berbasis syariah dan hasil investasinya diberikan kembali ke rekening tabarru' milik peserta. Serta secara umum pengelolaan dana tabarru' pada PT. Asuransi Takaful Keluarga Kabupaten Purbalingga dan PT. Asuransi Takaful Keluarga Purwokerto telah sesuai dengan prinsip syariah.
\end{abstract}

Kata-kata kunci : pengelolaan; Tabarru'; Asuransi Syariah; Dewan Syariah Nasional

\section{ABSTRACT}

One of the things that distinguishes between Islamic insurance and conventional insurance is the presence of tabarru funds in Islamic insurance. The Tabarru Fund is a help fund or grant. This article discusses the management of tabarru funds and the suitability in managing tabarru funds. The Fatwa Dewan Syariah Nasional Majelis Ulama Indonesia (the National Sharia Council of the Indonesian Ulema Council) Number. 53 / DSN-MUI / III / 2006 concerning akad tabarru'. Therefore, the results of the research in this article use a type of qualitative-descriptive research with interview data collection techniques and documentation. While the object of research is at PT. Takaful Keluarga 
Insurance in Purbalingga Regency and PT. Takaful Keluarga Insurance Purwokerto. The results of the research in this article show that every insurance product in PT. Takaful Keluarga Insurance in Purbalingga Regency and PT. Takaful Keluarga insurance Purwokerto has implemented the Tabarru Agreement. Overall fund management is divided into three, namely participant funds, company funds, and tabarru'. Tabarru 'funds are a help fund for disaster-affected sharia participants whose claim payments are allocated directly from tabarru' fund posts which are separated from other funds.Tabarru funds can be taken by submitting a claim, without claims, then tabarru funds cannot be taken. While the management aspects of tabarru funds collected by the Islamic insurance company are invested in sharia-based investment instruments and the return on investment is returned to the participant's tabarru account. As well as general management of tabarru funds at PT. Takaful Keluarga Insurance in Purbalingga Regency and PT. Takaful Keluarga insurance Purwokerto is in accordance with sharia principles.

Keywords: management; Tabarru '; Islamic Insurance; National Sharia Board

\section{PENDAHULUAN}

Kehidupan yang semakin kompleks pada saat ini memungkinkan akan mendatangkan risiko yang mengancam kehidupan manusia. Untuk menghadapi suatu risiko yang mungkin akan terjadi sewaktu-waktu, maka dari itu masyarakat hendaknya memiliki jaminan untuk menjamin kehidupan, kesehatan, kebahagiaan dihari tua, bahkan pendidikan untuk anak mereka. Salah satu tempat yang tepat untuk masyarakat untuk memperoleh jaminan tersebut yaitu asuransi. Perusahaan asuransi akan memberikan perlindungan proteksi terhadap risiko yang mungkin dihadapi oleh masyarakat, sehingga masyarakat merasakan keamanan karena mereka memiliki sebuah jaminan.

Potensi industri syariah di Indonesia sangat tinggi, mengingat jumlah penduduk muslim Indonesia sangat besar. Pertumbuhan pangsa pasar syariah sendiri juga sudah berkembang pesat. Hal ini juga mampu mendorong sektor keuangan negara baik yang berasal dari perbankan syariah, asuransi syariah, atau lembaga keuangan syariah yang lain. Oleh karena itu, diperlukan peran dan dukungan dari pemerintah dalam memberikan kebijakan-kebijakan terhadap lembaga keuangan syariah, khususnya entitas asuransi syariah agar dengan mudah dapat memperluas jaringan dan menambah pangsa pasarnya tidak hanya di dalam negeri, tapi juga sampai ke luar negeri (Hisamudin, 2015: 54-55). Perkembangan asuransi syariah di Indonesia pada awalnya hanya mengenal perusahaan asuransi syariah yakni Takaful Keluarga, kemudian disusul oleh 
perusahaan asuransi syariah lainnya, baik dalam bentuk asuransi full syariah maupun unit usaha syariah. Selain itu, adanya regulasi pemerintah tentang perasuransian terus dioptimalkan salah satunya dengan adanya revisi terhadap UU No. 2 Tahun 1992 tentang Usaha Perasuransian menjadi Undang-Undang Nomor 40 Tahun 2014 tentang Peransuransian, yang didalamnya mengatur secara lebih detail tentang keberadaan asuransi syariah.

Asuransi syariah berbeda dengan asuransi konvensional. Pada asuransi syariah setiap peserta sejak awal bermaksud saling menolong dan melindungi satu dengan yang lain, dengan menyisihkan dananya sebagai iuran kebijakan yang disebut tabarru'. Artinya, sistem asuransi syariah tidak melakukan pengalihan risiko (risk transfer) dimana tertanggung harus membayar premi, tetapi lebih merupakan pembagian risiko (risk sharing) dimana para peserta saling menanggung. Kemudian akad yang digunakan dalam asuransi syariah harus selaras dengan hukum Islam (syariah), artinya akad harus terhindar dari gharar (penipuan), maysir (perjudian), riba, zhulm (penganiayaan), risywah (suap), disamping itu investasi dana harus pada objek yang halal-thoyyibah bukan barang yang haram (Soemitra,2009: 245-246).

Akad pada asuransi syariah adalah akad tabarru' (hibah) untuk hubungan sesama peserta diamana pada dasarnya akad dilakukan atas dasar tolong menolong (taawun). Untuk hubungan antara peserta dengan perusahaan asuransi digunakan akad tijarah (ujrah/fee), mudharabah (bagi hasil), mudharabah musyarakah, wakalah bil ujrah (perwakilan), wadiah (titipan), syirkah (berserikat) (Soemitra, 2009: 266). Fatwa Dewan Pengawas Syariah Nasional Majelis Ulama Indonesia (DSN-MUI) Nomor : 53/DSN-MUI/III/2016 tentang Akad Tabarru' pada Asuransi Syariah. Perusahaan asuransi Takaful Keluarga menerapkan pemisahan entinitas pengelolaan dana menjadi tiga akun yakni dana tabarru', dana investasi peserta, serta dana perusahaan. Pembayaran klaim dialokasikan dari pos dana tabarru' yang sejak awal telah diniatkan untuk kepentingan tolong-menolong diantara peserta jika terjadi musibah. Dalam kondisi pos dana tabarru' mengalami defisit, menjadi kewajiban bagi perusahaan untuk menalanginya menggunakan dana perusahaan. Sementara pos dana peserta selamanya menjadi hak peserta yang menjadi tanggung jawab Takaful Keluarga untuk mengelolanya melalui instrumen investasi yang 
disepakati bersama. Dalam praktik di Takaful Keluarga pengelolaan dana tabarru' belum mengetahui bagaimana sistem pengelolaan dana tabarru' tersubut dan apakah sudah sesuai dengan prosedur yang berlaku di dalam Fatwa DSN-MUI.

Penelitian mengenai pengelolaan dana tabarru' pada asuransi syariah telah dilakukan oleh M. Arif Hakim (2012) menyebutkan bahwa pengelolaan dana tabarru' pada asuransi syariah telah sesuai dengan Fatwa DSN-MUI. Sulman Safinatus Shofiyah (2016) menjelaskan bahwa terdapat pengaruh positif dan signifikan pendapan premi terhadap cadangan dana tabarru'. Arief Fadlullah (2014) menyebutkan bahwa variabel pendapatan premi berpengaruh signifikan negatif terhadap rasio solvabilitas, sedangan variabel hasil investasi berpangaruh sighnifikan positif terhadap rasio solvabilitas, kemudian secara simultan semua variabel independen berpengaruh signifikan terhadap rasio solvabilitas. Al Torir Supiyanto (2015) terdapat pengaruh positif dan signifikan pendapatan oremi terhadap cadangan dana tabarru'. Novi Puspita (2012). menunjukkan bahwa penentuan proporsi tabarru'- ujrah dipengaruhi oleh faktor risiko, aspek keuangan perusahaan, dan kegiatan reasuransi syariah.

\section{TINJAUAN PUSTAKA}

Pengelolaan sama halnya dengan manajemen yang berarti suatu proses pengelolaan sumber daya untuk mewujudkan tujuan yang ingin dicapai. Manajemen mencakup fungsi perencanaan, pengorganisasian, penyusunan personalia, pengarahan dan pengawasan, sehingga dalam mengelola berbagai sumber daya, organisasi perlu menerapkan berbagai kegiatan seperti perencanaan berbagai kegiatan serta tujuan yang ingin dicapai, penyusunan secara terstruktur atas sejumlah pekerja yang digunakan, pengerahan dan pengarahan terhadap kegiatan para pekerja (Karyoto, 2016: 3). Adapun fungsi-fungsi pengelolaan dalam perusahaan asuransi syariah sama pengelolaan perusahaan atau organisasi lainnya yakni perencanaan, pengorganisasian, penggerakan, dan pengawasan (Makhrus, 2017: 71-74).

Sistem operasional asuransi syariah adalah saling bertanggung jawab, bantu-membantu, dan saling melindungi antara para peserta. Perusahaan asuransi syariah diberikan amanah oleh para peserta untuk mengelola premi, mengembangkan dengan jalan yang halal, dan memberikan 
santutan kepada peserta yang mengalami musibah (Syakir, 2004:176). Proses hubungan peserta dan perusahaan dalam mekanisme pertanggungan pada asuransi syariah adalah sharing of risk (saling menanggung risiko). Hal itu menunjukan bahwa sistem asuransi syariah adalah tolong menolong, yaitu dana yang terkumpul dalam bentuk dana tabarru' diinvestasikan dan dikembangkan dan hasilnya dapat digunakan untuk kepentingan peserta asuransi syariah (Rohmah\&Abidin, 2017:7). Keuntungan yang diperoleh dari pembagian dana peserta yang dikembangkan dengan prinsip mudharabah (sistem bagi hasil). Dimana peserta berkedudukan sebagai pemilik modal (shohibul maal) dan perusahaan asuransi sebagai pemegang amanah (mudharib). Keuntungan yang diperoleh dari pengembangan dana tersebut yang dibagi antar peserta dan perusahaan sesuai dengan ketentuan (nisbah) yang telah di sepakati (Syakir, 2004: 176-177).

Mekanisme pengelolaan dana peserta (premi) terbagi menjadi dua bagian yakni: pertama. sistem pada produk saving (tabungan) adalah alur mekanisme pengelolaan dana yang disertai dengan unsur tabungan dikelola dengan pendekatan, bahwa setiap iuran premi dari seorang peserta yang masuk keperusahaan asuransi syariah langsung di pecah menjadi dua bagian (Muhammad,2002:106). Kedua, sistem pada produk non saving (tidak ada tabungan) adalah mekanisme pengelolaan dana tanpa unsur tabungan (non saving), dikelola berdasarkan setiap premi yang diterima akan dimasukan kedalam rekening khusus, yaitu kumpulan dana yang diniatkan untuk tujuan kebijakan atau tabarru' guna pembayaran klaim pada peserta yang mengalami musibah atas harta benda yang menyebabkan pesera mengalami kerugian.

Tabarru' berasal dari kata tabarra'a-yatabarra'u-tabarru'an, yang artinya sumbangan atau derma. Orang yang menyumbang disebut mutabarri atau dermawan (Rahman, 2011:32). Jumhur Ulama mendefinisikan tabarru' dengan akad yang mengakibatkan pemilikan harta, tanpa ganti rugi, yang dilakukan seseorang dalam keadaan hidup kepada orang lain secara sukarela. Dalam arti yang lebih luas tabarru' adalah melakukan suatu kebaikan tanpa persyaratan. Tabarru' secara hukum fighiyah masuk ke dalam kategori akad hibah. Dalam salah satu definisi hibah oleh figh Al-Mu'amalat, Al-Shakr dikatakan bahwa hibah dengan pengertian umum adalah berderma/ber-tabarru' dengan harta untuk kemaslahatan orang lain 
dalam kondisi hidup (Puspitasari, 2012: 46).

Definisi akad tabarru' pada asuransi syariah dan reasuransi syariah menurut Dewan Syariah Nasional Majelis Ulama Indonesa (DSN MUI) yang tertuang dalam fatwa No. 53/DSN-MUI/III/2006 adalah semua bentuk akad yang dilakukan dalam bentuk hibah dengan tujuan kebajikan dan tolong menolong antar peserta, bukan untuk tujuan komersil (Puspitasari,2012: 46). Akad tabarru' adalah bentuk akad yang harus ada didalam asransi syariah yang dilakukan dalam bentuk hibah dengan tujuan tolong-menolong antar peserta asuransi syariah, dan tidak untuk tujuan komersil. Dana tabarru' adalah iuran/hibah sejumlah dana kepesertaan asuransi yang diberikan oleh peserta asuransi syariah individu kepada peserta secara kolektif (kumpulan dana tabarru' (pooling fund) sesuai dengan kesepakatan (Makhrus, 2017: 63). Pengembalian dana tabarru' adalah pengembalian sebagaian dana tabarru' kepada peserta asuransi secara individu karena berhenti sebelum masa perjanjian berakhir (Makhrus, 2017: 63). Kata asuransi berasal dari bahasa Belanda assurantie, dan dalam bahasa hukum belanda digunakan dengan kata verzekering. Sedangkan dalam bahasa Inggris disebut dengan insurance. Kata tersebut kemudian didalam dalam bahasa Indonesia dengan kata pertanggungan (Ismanto, 2009: 20). Menurut Wirjono Prodjodikoro, asuransi adalah suatu persetujuan pihak yang menjamin dan berjanji kepada pihak yang dijamin, untuk menerima sejumlah uang premi sebagai pengganti kerugian yang mungkin akan diderita oleh dijamin karena akibat dari suatu peristiwa yang belum jelas (Zainudin, 2008: 1).

Asuransi syariah adalah asuransi dalam bahasa Arab dikenal dengan istilah at-ta'min, penanggung disebut mu'aimin, sedangkan tertanggung disebut mu'amman lahu atau musta'min. Kata at-ta'min diambil adari kata amana yang menmiliki arti memberi perlindungan, ketenangan, rasa aman dan bebas dari rasa takut. Menurut Fatwa Dewan Syariah Nasional No: 21/DSN-MUI/X/2001 tentang Pedoman Umum Asuransi Syariah menjelaskan bahwa asuransi syariah (Ta'min, Takaful atau Tadhamun) adalah usaha saling melindungi dan tolong-menolong di antara sejumlah orang/ pihak melalui investasi dalam bentuk aset dan atau tabarru' yang memberikan pola pengembalian untuk menghadapi resiko tertentu melalui akad (perikatan) yang sesuai dengan syariah (Makhrus,2017:15). Dapat disimpulkan asuransi syariah adalah perjanjian antara dua orang atau lebih 
untuk saling tolong menolong, saling melindungi satu sama lain untuk mendapatkan rasa aman, dengan tujuan meminimalisir risiko yang mungkin akan terjadi.

Prinsip asuransi syariah sangat berbed dengan prinsip asuransi konvensional. Prinsip dalam asuransi syariah harus berlandaskan berdasarkan Al-Quran dan Sunnah. Adapun prinsip-prinsip asuransi syariah menurut para pakar ekonomi Islam adalah saling bertanggung jawab, saling bekerja sama atau saling membantu, saling melindungi penderita satu sama lainnya (Dewi, 2005: 166). Kesadaraan seseorang memiliki asuransi adalah menyiapkan proteksi untuk diri sendiri dan kelurganya dari berbagai kemungkinan resiko yang tidak terduga akan terjadi di masa depan. Untuk dapat memahami dan meiliki kesadaran akan pentingnya memiliki asuransi, maka terdapat beberapa manfaat asuransi yaitu: memberikan arasa aman dan perlindungan, memberikan kepastian dengan mengurangi tingkat kerugian atau kerusakan, sarana menabung, meminimalisir sebuah resiko, menjadikan hidup lebih tenang, dan membantu meningkatkan kegiatan usaha tertanggung (Makhrus, 2017: 40).

\section{METODE PENELITIAN}

Jenis penelitian adalah penelitian kualitatif deskriptif. Sumber data yang akan digunakan dalam penelitian ini ada dua jenis yaitu sumber data primer dan sumber data sekunder. Sumber data primer adalah dan wawancara. Sedangkan sumber data sekunder adalah dokumen-dokumen resmi, buku, majalah, buletin, dan publikasi dari berbagai organisasi, sehingga sumber data dalam penelitian adalah wawacara dan dokumentasi. Objek penelitian ini adalah PT. Asuransi Takaful Keluarga Kabupaten Purbalingga dan PT. Asuransi Takaful Keluarga Purwokerto dengan analisis data menggunakan metode penelitian kualitatif yang bertolak dari asumsi tentang realitas atau fenomena sosial yang bersifat unik dan kompleks dengan menggambarkan dan menginterpretasikan data-data yang telah terkumpul, kemudian memberikan perhatian dan merekam sebanyak mungkin aspek situasi yang diteliti, sehingga memperoleh gambaran secara umum dan menyeluruh tentang keadaan sebenarnya.

\section{HASIL DAN PEMBAHASAN}

Takaful keluarga adalah pelopor perusahaan asuransi jiwa syariah di Indonesia. Takaful keluarga mulai beroperasi sejak tahun 1994. Takaful 
keluarga mengembangkan berbagi produk untuk kebutuhan berasuransi syariah yang meliputi perlindungan jiwa, perlindungan kesehatan, perencanaan pedidikan anak, perencanaan hari tua, serta menjadi rekan terbaik dalam perencanaan investasi. Dalam kualitas operasional dan pelayanan, Takaful Keluarga telah memperoleh sertifikasi ISO 9001: 2008 dari Det Norske Veritas (DVN), Norwegia pada November 2009 sebagai standar internasional mutakhir untuk sistem manajemen mutu. Selain itu, Takaful Keluarga terdaftar dan diawasi oleh Otoritas Jasa Keuanga (OJK) serta memiliki tenaga pemasaran yang terlisensi oleh Asosiasi Asuransi Jiwa Indonesia (AAJI) dan Asosiasi Asuransi Syariah Indonesia (AASI).

Produk dalam perusahaan asuransi syariah sangat penting bagi perusahaan dan peserta asuransi. Dimana produk tersebut dapat menarik peserta untuk dapat bergabung dan berasuransi. Adapun produk-pruduk asuransi pada PT. Asuransi Takaful Keluarga yaitu takaful personal, Takaful Korporat, dan Takaful Bancassurance. Artinya, PT. Asuransi Takaful Keluarga Kabupaten Purbalingga dan Purwokerto menghadirkan solusi perencanaan keuangan syariah untuk individu melalui berbagai produk proteksi dan investasi yang tidak hanya memberikan ketenangan hidup tetapi juga menciptakan hubungan silaturahmi dan saling berbagi antar nasabah lainnya. Pengelolaan dana tabarru' adalah mengelola dana tolong menolong antar peserta dengan cara yang sesuai dengan syariat Islam, keuntungan yang diperoleh dari hasil investasi dana tabarru' dengan prinsip mudharabah (bagi hasil). PT. Asuransi Takaful Keluarga Kabupaten Purbalingga dan Purwokerto tentang pengelolaan dana. Dana tabarru' menjadi dana tolong-menolong antara peserta asuransi syariah yang terkena musibah dan tarus ada di asuransi syariah. Sebab keberadaan dana tabarru' menjadi salah satu yang membedakan antara asuransi syariah dengan asuransi konvensional.

Pengelolaan dana pada PT. Takaful Keluarga menerapkan pemisahan entitas dana menjadi tiga akun yakni dana tabarru', dana investasi peserta, dan dana perusahaan. Pembayaran klaim dialokasikan dari pos dana tabarru' yang sejak awal diniatkan untuk kepentingan tolong-menolong di antara peserta jika terjadi musibah. Namun, dalam kondisi pos dana tabarru' mengalami defisit, maka hal ini menjadi kewajiban perusahaan untuk menalanginya dengan menggunakan dana perusahaan. Sementara pos dana peserta akan selamanya menjadi hak peserta yang menjadi 
tanggung jawab Takaful Keluarga untuk mengelolanya melalui instrumen investasi yang disepakati bersama. Sedangkan pengelolaan dana tabarru' oleh perusahaan diinvestasikan melalui lembaga keuangan syariah seperti pasarmodal syariah, saham syariah, reksadana syariah, dana obligasi syariah (sukuk). Investasi dana tabarru' tersebut harus melalui persetujuan Dewan Pengawas Syariah (DPS) untuk memantau dana tabarru' yang diinvestasikan ke hal-hal yang halal. Semua dana yang diinvestasikan dan hasil investasi dari dana tersebut kembali ke rekening. Apabila terjadi surplus underwriting dana tabarru', maka alokasi atau pembagian dari surplus tersebut dialokasikan sebagai jenis asuransi dengan tabungan dan jenis asuransi non tabungan. Kedua jenis pengelolaan dana yang terdapat di PT. Asuransi Takaful Keluarga Kabupaten Purbalingga, nisbah dana tabarru' diberikan apabila perusahaan terjadi surplus underwriting, namun apabila perusahaan tidak terjadi surplus underwriting atau minus maka peserta tidak mendapatkan nisbah (bagi hasil). Oleh sebab itu, setiap dana peserta yang disetorkan ke PT. Asuransi Takaful Keluarga Kabupaten Purbalingga, kemudian dana yang telah masuk di investasikan ke instrumen investasi syariah yang telah ditentukan atau disetujui oleh DPS kantor pusat PT. Asuransi Takaful Keluarga (Paminto, 15/11/2018). Adapun proses pengelolaan dana tabarru' sebagai berikut :

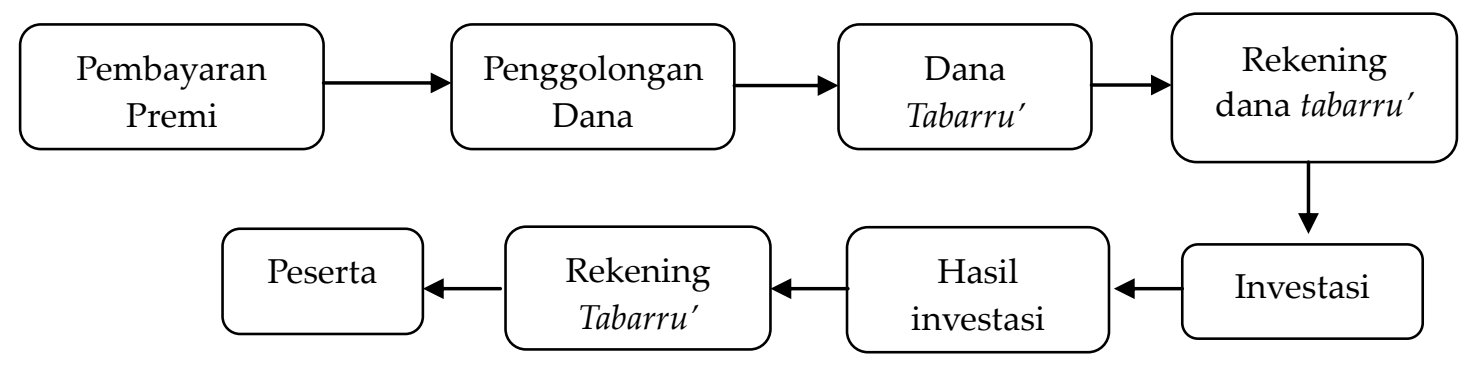

Gambar 1 : Skema Pengelolaan Dana Tabarru'

Pengelolaan dana tabarru' yang dilakukan oleh PT. Takaful Keluarga dalam berbagai investasi berbasis syariah. Maka, proses pencairan dana tabarru'dapat dicairkan dengan dua cara, yaitu mengajukan klaim dan pengajuan surplus underwriting, hal ini dikarenakan dana tabarru' sebagai dana tolong menolong untuk peserta yang terkena musibah, sehingga pencairan dana tabarru' hanya dapat dilakukan apabila peserta mengalami musibah dengan mengajukan klaim. Dalam PT. Asuransi Takaful Keluarga Kabupaten Purbalingga dan PT. Takaful Keluarga Purwokerto terdapat dua 
jenis klaim yaitu klaim risk dan klaim non risk.

Kesesuaian pengelolaan dana tabarru' di PT. Asuransi Takaful Keluarga Purbalingga dan PT. Asuransi Takaful Purwokerto dengan Fatwa DSN MUI No. 53/ DSN-MUI/ III/ 2006 tentang akad tabarru' pada Asuransi Syariah telah menerapkan akad tabarru' dimana akad tabarru' adalah akad yang harus ada pada perusahaan asuransi syariah mana pun. Dalam praktinya semua peserta atau pemegang polis. Kedudukan para pihak dalam akad tabarru' yaitu, pertama peserta membayarkan dana tabarru' untuk tujuan saling tolong menolong antar peserta yang sedang terkena musibah. Kedua, peserta asuransi di PT. Asuransi Takaful Keluarga merupakan pihak yang berhak untuk memperoleh dana tabarru' apabila peserta tersebut mengalami musibah, sedangkan PT. Asuransi Takaful Keluarga sebagai pihak yang yang menanggung. Ketiga, PT. Asuransi Takaful Keluarga Kabupaten Purbalingga PT. Asuransi Takaful Purwokerto bertindak sebagai pengelola dana tabarru' atas dasar kada wakalah dari para peserta.

Pengelolaan dana tabarru' pada PT. Asuransi Takaful Keluarga dilakukan oleh suatu lembaga menjadi pemegang amanah dimana lembaga tersebut sudah melalui persetujuan dari Dewan Pengawas Syariah. Selain itu, dalam pengelolaan dana tabarru' pembukuannya pun terpisah dari dana yang lain. Dana tabarru' kemudian di investasikan dan hasil dari investasi tersebut kemudian menjadi hak kolektif peserta dan masuk dalam rekening tabarru'. Surplus underwriting yang terdapat pada dana tabarru' kemudian dimasukan kedalam akun tabarru' atau diberikan kepada peserta yang sedang terkena musibah. Perusahaan asuransi syariah memperoleh bagi hasil dari investasi berdasarkan akad mudharabah atau mudharabah musyarakah, atau memperoleh ujrah (fee) berdasarkan akad wakalah (Paminto, 15 November 2018).

Dana tabarru' yang telah dibayarkan oleh peserta asuransi tidak boleh diminta kembali, seperti yang sudah dijelaskan di atas dana tabarru' merupakan dana tolong menolong antar peserta yang terkena musibah. Dana tabarru' dapat diminta kembali apabila peserta yang meminta terkena musibah. Dalam mengembalian dana tabarru' pun peserta harus mengajukan klaim terlebih dahulu, sehingga dapat mendaptkan dana tabarru' tersebut. PT. Asuransi Takaful Keluarga dalam pengembalian dana tabarru' apabila terjadi surplus underwriting namun apabila tidak terjadi 
surplus underwriting maka dana tabarru' tidak dapat dikembalikan. Jika terjadi Surplus underwriting atas dana tabarru', maka dapat dilakukan dengan cara surplus underwriting digunakan untuk cadangan dalam akun tabarru'. Dapat juga disimpan sabagai cadangan dana tabarru' dan diberikan kepada peserta yang sedang mengalami musibah. Dan surplus underwrting dapat disimpan sebagai dana cadangan tabarru' dan diberikan sebagian kepada perusahaan atas dasar kesepakatan awal dengan peserta. Jika terjadi defisit underwriting atas dana tabarru' maka perusahaan yang bertanggung jawab untuk menanggulangi kekurangan tersebut dalam bentuk qard (pinjaman). Dalam pengembalian gard (pinjaman) kepada perusahaan asuransi dapat diambil dari dana tabarru' (Paminto, 15/11/2018).

Dana tabarru' yang telah dibayar tidak boleh diminta kembali, adapun ketentuan fatwa yang mengatur tentang pengembalian dana tabarru' yaitu terdapat dalam Fatwa DSN-MUI Nomor 81/ DSN-MUI/III/2011 tentang pengembalian dana tabarru' bagi peserta asuransi yang berhenti sebelum masa perjanjian berakhir. Adapun ketentuan yang mengatur tentang pengembalian dana tabarru', yaitu peserta asuransi syariah tidak boleh meminta kembali dana tabarru' yang sudah dibayarkan, perusahaan asuransi sebagai pengelola dana tabarru' tidak berwenang mengembalikan dana tabarru', peserta asuransi syariah sebagai penerima dana tabarru' memiliki wewenang dalam memmuat aturan tentang penggunaan dana tabarru' dan pengembalian dana tabarru' sebelum berakhirnya perjanjian, namun kewenangan tersebut dinyatakan secara jelas sejak dilakukannya akad.

PT. Asuransi Takaful Keluarga merupakan perusahaan asuransi syariah pertama yang didirikan di Indonesia, yang terus berkembang hingga sekarang. Mengingat akan pentingnya pengelolaan dan peserta asuransi, maka dana peserta dikelola dengan baik oleh pihak perusahaan. Upaya yang perlu di tingkatkan lagi dalam pengelolaan dana peserta yaitu dengan melihat fungsi pengelolaan itu sendiri. Adapun beberapa fungsi pengelolaan dana yang perlu diperhatikan perencaan, pengorganisasian, penggerakan, dan pengawasan (Makhrus, 2017: 71-74). Pengelolaan dana pada perusahaan asuransi syariah dengan sistem operasional asuransi syariah adalah saling bertanggung jawab, bantu-membantu, dan saling melindungi antara para peserta. Perusahaan asuransi syariah diberikan 
amanah oleh para peserta untuk mengelola premi, mengembangkan dengan jalan yang halal, dan memberikan santutan kepada peserta yang mengalami musibah. Keuntungan yang di peroleh dari pembagian dana peserta yang dikembangkan dengan prinsip mudharabah (sistem bagi hasil). Dimana peserta berkedudukan sebagai pemilik modal (shohibul maal) dan perusahaan asuransi sebagai pemegang amanah (mudharib). Keuntungan yang diperoleh dari pengembangan dana tersebut yang dibagi antar peserta dan perusahaan sesuai dengan ketentuan (nisbah) yang telah disepakati (Syakir, 2004:176-177).

PT. Asuransi Takaful Keluarga Kabupaten Purbalingga dan PT. Asuransi Takaful Keluarga Purwokerto dalam pegelolaan dana peserta asuransi di kelola oleh kantor pusat PT. Asuransi Takaful Keluarga. Dimana dana yang dikumpulkan perusahaan kemudian diinvestasikan ke dalam inverstasi yang halal dan sudah memiliki izin dari Dewan Pengawas Sayariah. Keuntungan yang diperoleh dari investasi kemudian dibagi menjadi tiga yaitu untuk peserta, perusahaan dan dana tabarru'. Pembagian keuntungan itu sendiri sesuai dengan kesepakatan diawal perjanjian antara perusahaan dengan peserta asuransi.

Pengelolaan dana pada PT. Asuransi Takaful Keluarga dibagi menjadi tiga kelompok yaitu: pertama, dana perusahaan atau biaya yaitu dana yang digunakan oleh perusahaan untuk operasional perusahaan. Kedua, dana tabungan yaitu dana milik peserta yang dibayarkan setiap bulannya, dan peserta dapat mengambil dana tersebut kapanpun peserta inginkan, namun harus sesuai dengan kesepakatan di awal. Ketiga, dana tabarru' yaitu dana tolong menolong antar peserta asuransi syariah yang digunakan untuk menolong sesama pserta asuransi syariah yang terkena musibah. Pada PT. Asuransi Takaful Keluarga pengelolaan dana asuransi pada produk saving (tabungan) melalui iuran premi dari para peserta asuransi, kemudian dikelompokan menjadi tiga dan memiliki presentase yang berbeda-beda, yaitu: peserta $0 \%$, perusahaan $0 \%$, dan dana tabarru' $100 \%$ (Paminto, 15/11/2018). Sistem ini sebagai implementasi dari akad takafuli dan mudharabah, sehingga asuransi syariah dapat terhindar dari unsur gharar dan maisir. Presentase pembagian mudharabah dibuat dalam suatu perbandingan tetap berdasarkan perjanjian kerja sama antara perusahaan asuransi dan peserta, misalnya dengan 70: 30, 60: 40 dan seterusnya (Syakir, 2004: 177). Dana tabarru' yang terdapat dalam PT. Asuransi Takaful 
Keluarga memiliki tujuan sebagai dana tolong menolong antar peserta asuransi yang sedang terkena musibah, presentasi yang pembagian hasil investasi juga sudah disepakati oleh para peserta di awal perjanjian. Dana tabarru' yang ada pada PT. Asuransi Takaful Keluarga tidak berhenti diperusahaan, namun dana tabarru' tersebut diinvestasikan oleh pihak perusahaan melalui instrumen investasi syariah melalui persetujuan dari Dewan Pengawas Syariah, karena dalam asuransi syariah dalam menginvestasi semua dana yang ada harus di investasikan ke arah yang halal saja. Semua dana yang telah di investasikan dan hasil dari investasi tersebut kemudian kembali lagi ke rekening peserta asuransi (Paminto, 15/11/2018). Akad tabarru' sebagai akad tolong menolong antar peserta asuransi untuk membantu peserta lain yang terkena musibah. Dalam praktiknya akad tabarru' yang berada di perusahaan asuransi menggunakan Fatwa DSN-MUI sebagai pedoman untuk menjalankan akad tabarru' dengan baik sesuai dengan syariat Islam dimana telah ditetapkan Fatwa DSN-MUI No. 53/DSN-MUI/III/2006 tentang akad tabarru' pada asuransi syariah.

Praktik dana tabarru' pada PT. Asuransi Takaful Keluarga Kabupaten Purbalingga dan PT. Asuransi Takaful Purwokerto berdasarkan ketentuan hukumnya akad tabarru'harus melekat pada semua produk asuransi, semua bentuk akad yang dilakukan antar peserta pemegang polis, dan asuransi syariah dalam konteks ini adalah asuransi jiwa, asuransi kerugian, dan reasuransi. Pada kedua cabang perusahan asuransi tersebut di atas, telah mengaplikasikan akad tabarru' pada perusahaan sesuai dengan fatwa yang telah di tetapkan oleh Dewan Syariah Nasional. Hal tersebut ditandai dengan bahwa akad tabarru' yang dilakukan dalam bentuk hibah dengan tujuan kebajikan dan tolong menolong antar peserta, bukan untuk tujuan komersial. Selain itu, akad Tabarru' disebutkan sekurang-kurangnya hak dan kewajiban masing-masing peserta secara individu, hak dan kewajiban antara peserta secara individu dalam akun tabarru' selaku peserta dalam arti badan/kelompok, cara dan waktu pembayaran premi dan klaim, syarat-syarat lain yang disepakati, sesuai dengan jenis asuransi yang diakadkan.

Pengelolaan dana tabarru' yang telah diatur dalam Fatwa DSN MUI yaitu: pertama, pengelolaan asuransi dan reasuransi syariah hanya boleh dilakukan oleh suatu lembaga yang berfungsi sebagai pemegang amanah, 
Kedua, pembukuan dana tabarru' harus terpisah dari dana lainnya. Ketiga, hasil investasi dari dana tabarru' menjadi hak kolektif peserta dan dibukukan dalam akun tabarru', Keempat, dari hasil investasi, perusahaan asuransi dan reasuransi syariah dapat memperoleh bagi hasil berdasarkan akad mudharabah atau akad mudharabah musytarakah, atau memperoleh ujrah (fee) berdasarkan akad wakalah bil ujrah (Fatwa DSN-MUI). Dalam pengelolaan dana tabarru' di PT. Asuransi Takaful Keluarga Kabupaten Purbalingga dan PT. Asuransi Takaful Purwokerto pengelolaan dana dilakukan di kantor pusat, sehingga pihak hanya mengetahui dana yang telah terkumpul, kemudian diinvestasikan ke lembaga yang halal. Selain itu, pembukuan dana tabarru' dipisah dengan dana lainnya. Adapun hasil investasi dari dana tabarru' merupakan hak kolektif milik peserta dan dibukukan dalam rekening tabarru'. Sedangkan sebagian hasil investasi dana tabarru' dapat diberikan kepada perusahaan dan dapat dicadangkan untuk dana tabarru' sesuai dengan kesepakatan peserta diawal perjanjian.

Jika terjadi surplus underwriting dapat dilakukan dengan alternatif, semua dana dicadangkan dalam akun tabarru', disimpan sebagian dana cadangan dan dibagikan sebagian kepada peserta yang memenuhi syarat, dan disimpan sebagian sebagai dana cadangan tabarru' dan dapat diberikan keperusahaan sesuai dengan kesepakatan peerta. Jika terjadi Surplus underwriting atas dana tabarru', maka dapat dilakukan dengan cara surplus underwriting digunakan untuk cadangan dalam akun tabarru'. Dapat juga disimpan sabagai cadangan dana tabarru' dan diberikan kepada peserta yang sedang mengalami musibah. Dan surplus underwrting dapat disimpan sebagai dana cadangan tabarru' dan diberikan sebagian kepada perusahaan atas dasar kesepakatan awal dengan peserta. Sementara jika terjadi defsist underwriting atas dana tabarru' maka perusahaan wajib menanggulangi kekurangan tersebut dalam bentuk qardh (pinjaman). Pengembalian dana qardh (pinjaman) kepada perusahaan asuransi disishkan dari dana tabarru'. Jika terjadi defisit underwriting atas dana tabarru' maka perusahaan yang bertanggung jawab untuk menanggulangi kekurangan tersebut dalam bentuk qard (pinjaman). Dalam pengembalian qard (pinjaman) kepada perusahaan asuransi dapat diambil dari dana tabarru'. 


\section{SIMPULAN}

Pengelolaan dana pada PT. Asuransi Takaful Keluarga Kabupaten Purbalingga dan PT. Asuransi Takaful Purwokerto terbagi menjadi tiga kelompok yaitu, dana perusahaan, dana peserta dan dana tabarru'. Dana tabarru' merupakan dana tolong menolong antar peserta asuransi terhadap peserta lain yang terkena musibah. Pengelolaan dana tabarru' di PT. Asuransi Takaful Keluarga yaitu dengan dana yang sudah terkumpul kemudian dipisahkan dari dana lainnya dan dibukukan dengan buku rekening tabarru', dana tabarru' kemudian diinvestasikan kembali melalui instrumen investasi berbasis syariah seperti pasar modal syariah, saham syariah, reksadana syariah, dan obligasi syariah (sukuk). Hasil dari investasi dana tabarru' masuk ke rekening tabarru', apabila terjadi surplus underwriting. Dalam menginvestasikan dana tabarru' harus mendapat persetujuan dari Dewan Pengawas Syariah. Dana tabarru' dapat dicairkan dengan cara pengajuan klaim, tanpa pengajuan klaim dana tabarru' tidak dapat dicairkan. Pengelolaan dana tabarru' pada PT. Asuransi Takaful Keluarga Kabupaten Purbalingga dan PT. Asuransi Takaful Purwokerto telah sesuai dengan Penerapan Fatwa DSN-MUI No. 53/DSN-MUI/III/2006 tentang Akad Tabarru' pada Asuransi Syariah. Dalam Fatwa disebutkan bahwa pengelolaan dana tabarru' hanya boleh dilakukan oleh satu lembaga yang menjadi pemegang amanah, serta pembukuan dana tabarru' juga telah sesuai dengan Fatwa, yaitu pembukuan dana tabarru' terpisah dengan dana lainnya.

\section{DAFTAR REFERENSI}

Fadlullah, Arief. "Pengaruh Pendapatan Premi dan Hasil Investasi Terhadap Cadangan Dana Tabarru' (Studi Pada PT. Asuransi Sinarmas Syariah)." (2014).

Hakim, M. Arif. "Analisis Aplikasi Akad Tabarru'dalam Asuransi Syariah: Studi Kasus pada AJB Bumiputera 1912 Syariah Cabang Kudus." Muqtasid: Jurnal Ekonomi dan Perbankan Syariah 3.2 : 231-249. (2012).

Hisamuddin, Nur. "Implementasi Akuntansi Akad Wakalah Bil Ujrah Perusahaan Asuransi Syariah Berdasarkan PSAK 108: Studi di PT Asuransi Takaful Keluarga." ADDIN 8.1. (2015).

Kendari. Jurusan Tarbiyah STAIN Sultan Qaimuddin. "Keterampilan 
Mengelola Kelas dan Implementasinya dalam Proses Pembelajaran." Jurnal Al-Ta'dib Vol 7.2. (2012).

Muslim, Shohib, and Khrisna Hadiwinata. "Tinjauan Hukum Terhadap Kedudukan Fatwa Dewan Syariah MUI dalam Usaha Asuransi di Indonesia." qolamuna: Jurnal studi islam 3.2: 149-166. (2018).

Saniatusilma, Hifi, and Noven Suprayogi. "Manajemen Risiko Dana Tabarru'PT. Asuransi Jiwa Syariah Al Amin." Jurnal Ekonomi Syariah Teori dan Terapan 2.12. (2015).

Shofiyah, Sulma Safinatus. "Pengaruh Pendapatan Premi, Klaim Dan Hasil Investasi Terhadap Cadangan Dana Tabarru'pada Perusahaan." (2016).

Supriyanto, Al Torik. Pengaruh Pendapatan Premi Dan Hasil Investasi Terhadap Cadangan Dana Tabarru' Pada Perusahaan Asuransi Syariah Di Indonesia. (2015).

Suripto, Teguh, and Abdullah Salam. "Analisa Penerapan Prinsip Syariah dalam Asuransi." JESI (Jurnal Ekonomi Syariah Indonesia) 7.2: 128-137. (2018).

Puspitasari, Novi. "Model Proporsi Tabarru'Dan Ujrah Pada Bisnis Asuransi Umum Syariah Di Indonesia." Jurnal Akuntansi dan Keuangan Indonesia 9.1: 43-55. (2012).

Rohmah, Wahidatur, and Zainal Abidin. "Studi Komparatif Asuransi Syari'ah dan Asuransi Konvensional Dalam Perspektif Hukum Islam." AL MUNAZHZHARAH 1.1: 22-35. (2017).

Rahman, Fudhail. "Asuransi Dalam Perspektif Hukum Islam." Jurnal Al'Adalah 10 : 25-34. (2011).

Bungin, Burhan. 2011. Metodol 60 'elitian Sosial. Surabaya: Airlangga Universiti Press.

Ghofur, Abdul. 2010. Hukum ı слипґın Islam Di Indonesia. Yogyakarta: Gajah Mada Universiti Press.

Gemala, Dewi. 2005. Hukum Perikatan Islam Di Indonesia. Jakarta: Kencana Prenada Media Group.

Herdiansyah, Haris. 2011. Metodologi Penelitian Kualitatif Ilmu Sosial. Jakarta: Salmb Humanika.

Karyoto. 2016. Dasar-Dasar Manajemen. Yogyakarta: CV Andi Offset. Makhrus. 2017. Manajamen Asuransi Syariah. Yogyakarta: Litera.

Manan, Abdul. 2012. Hukum Ekonomi Syariah Dalam Prespektif Kewenangan Peradilan Agama. Jakarta: Kencana Prenada Media Group. 
Mardani. 2017. Aspek Hukum Lembaga Keuangan Syariah Di Indonesia. Jakarta: Kencana.

Muhammad. 2000. Sistem dan prosedur Operasional Bank Islam. Yogyakarta: UII Press Yogyakarta.

Rahman, Abdul. 2010. Fiqh Muamalat. Jakarta: Kencana Prenada Media Group.

Syakir, Sula. 2004. Asuransi Syariah (Life And General) Konsep Dan Sistem Operasional. Jakarta: Gema Isani.

Soemitra, Andri. 2009. Bank \& Lembaga Keuangan Syariah. Jakarta: Kencana Media Group.

Zainudin. 2008. Hukum Asuransi Syariah. Jakarta: Sinar Grafika

Fatwa DSN-MUI No. 53/DSN-MUI/III/2006

Wawancara: Ikhsanudin Kepala Pimpinan PT. Asuransi Takaful Keluarga Kabupaten Purbalingga \& Paminto Kepala Pimpinan PT. Asuransi Takaful Keluarga Purwokerto. 